\title{
Effect of Harvest Period on Foliage Production and Dry Matter Distribution in Five Cassava Cultivars During the Second Plant Cycle
}

\author{
Edvaldo Sagrilo ${ }^{1}$, Pedro Soares Vidigal Filho ${ }^{2 *}$, Manoel Genildo Pequeno ${ }^{2}$, Maria Celeste \\ Gonçalves Vidigal ${ }^{2}$, Carlos Alberto Scapim², Marcus Vinícius Kvitschal ${ }^{3}$, Rogério Rui \\ Maia $^{3}$ and Fabrício Rimoldi ${ }^{3}$ \\ ${ }^{1}$ Empresa Brasileira de Pesquisa Agropecuária - EMBRAPA; BR 163; Km 253; Trecho Dourados-Caarapó; C. P. \\ 661; sagrilo@cpao.embrapa.br; 79804-970; Dourados - MS - Brasil. ${ }^{2}$ Departamento de Agronomia; ${ }^{3}$ Programa de \\ Pós-Graduaçào em Genética e Melhoramento; Universidade Estadual de Maringá - UEM; Av. Colombo, 5790; \\ psvfilho@uem.br; marcusvk78@hotmail.com; 87020-570; Maringá - PR - Brasil
}

\begin{abstract}
The objective of this work was to study the leaf production pattern and dry matter distribution in cassava during the second plant cycle. The completely randomized experimental design with four replications was used, with five cultivars in the main plots and ten harvest times in the sub-plots. Foliage production was affected by plant age, being higher in hot periods. Leaf blades and petioles dry matter content presented a linear increase due to a progressive decrease in the amount of young leaves and ontogenetic factors. The stems provided, temporarily, carbohydrates to the plant re-growth, delaying the availability and use of storage roots dry matter. The dry matter content in the storage roots was lower during the vegetative and higher during rest period. The storage roots diameter increased considerably when the amount of leaves was higher, indicating the importance of leaf area in the cassava plant production.
\end{abstract}

Key words: Manihot esculenta Crantz, harvesting period, foliage production, dry matter distribution

\section{INTRODUCTION}

Cassava (Manihot esculenta Crantz) is a shrub plant from the Euphorbiaceae family and its cultivation has been associated in Brazil since its discovery (Cardoso and Souza, 2002). Cassava is mainly cultivated because of its starchy storage roots and it is considered one of the most important staple food in the tropical countries. It represents the fourth largest source of energy (Alves, 2002) besides being a very important animal feed and industrial raw material (Doretto,
1993; Cardoso and Souza, 2002). According to Scott et al. (2000), cassava is one of the crops with the highest annual cultivation area increase (about $2 \%$ ), being similar to corn (Zea Mays) and only inferior to potatoes (Solanum tuberosum). In Brazil, the total production of cassava roots in the 2004/2005-year was of 27.66 million tons in an area of 1.94 million hectares, with an average yield of 14.25 t.ha $^{-1}$ (IBGE, 2006). Paraná State presented a production of 4.18 million tons in an area of 205 thousand hectares with an average yield of 20.37 t.ha ${ }^{-1}$ (IBGE, 2006), despite being

\footnotetext{
* Author for correspondence
} 
the highest index in Brazil. This is still low considering the cassava productivity potential (Sagrilo et al., 2002a).

Although cassava is considered a perennial plant, its starchy storage roots are commercially harvested from 6 to 24 months of age according to the cultivar and growth conditions (El Sharkawy, 1993). In humid low-lands in tropical countries, the roots can be harvested after 6-7 months (Cock, 1984), and in areas of cold and drought periods they are harvested after 18-24 months. Results obtained by Sagrilo et al. (2002b) in Araruna, Northwest of Paraná emphasized that cassava harvested at 21 months could improve its storage roots yield, in the order of $93.5 \%$, compared to crops of only one vegetative plant cycle. Despite the existence of more adequate periods for cassava harvest, in some Brazilian states it has been performed almost all year long, which characterises a particular condition of this country. Several characteristics are associated to the yield of cassava and among the most important, are those related to the foliage production, leaf life length, and assimilates distribution (Veltkamp, 1985). According to Cock et al. (1979), an increased leaf life and, consequently, a longer period of plant photosynthesis are important factors to obtain an increase in the cassava storage roots yields. Veltkamp (1985) reported that variations in the storage roots production occured in function of the differences in the leaf area or in its life length. Sangoi and Kruse (1993) found that the plant foliage maintenance for a long period allowed to keep the assimilates flow to the root system more efficiently, leading to high accumulation of dry matter in the storage roots. On the other hand, the dry matter accumulation in the stalks is another important factor for the cassava productivity efficiency, considering both, the quality of the planting material and the conduct feature (Jesus et al., 1986), which was responsible for the carbohydrates supply to the plant vegetative portion in the sprout periods (Sales Filho, 1980) and to the storage roots during the physiological rest period (Conceição, 1981; Alves, 2002).

There are few papers describing the behaviour of dry matter contents in different cassava organs during the plant cycle as well as its relation to the foliage production. For this reason, this paper aimed to study the pattern of foliage production and dry matter distribution in different organs of five cassava cultivars in different harvest times during the second plant cycle.

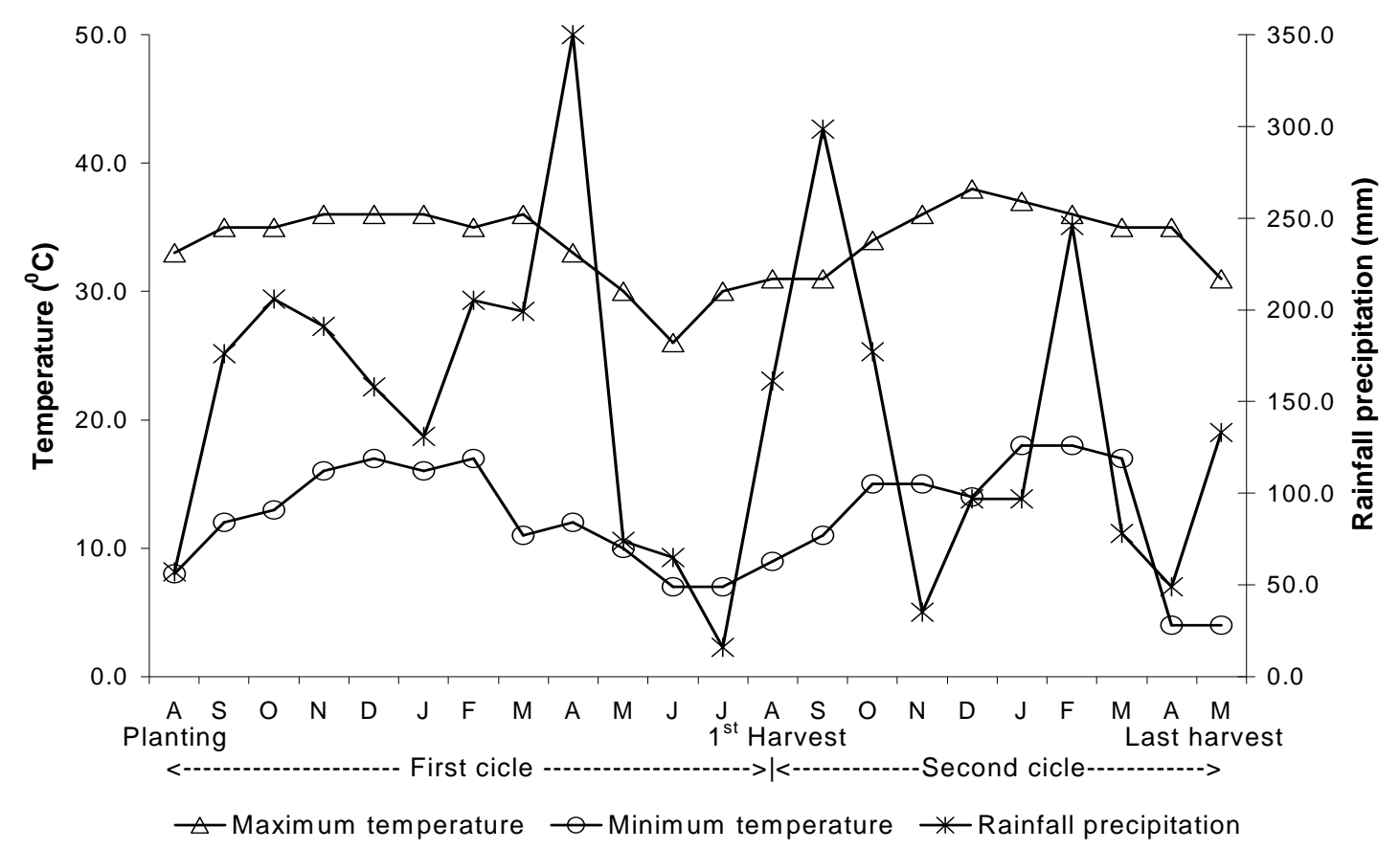

Figure 1 - Rainfall and maximum and minimum temperatures from August 1997 to May 1999 in Araruna, Paraná, Brazil 


\section{MATERIALS AND METHODS}

The experiment was carried out from October 1997 to May 1999 in a distrophic Red Latosoil (Embrapa, 1999), located in Araruna, Northwest of Paraná State $\left(23^{\circ} 55^{\prime}\right.$ South Latitude and $52^{\circ}$ o $30^{\prime}$ West Longitude). Araruna presents $660 \mathrm{~m}$ average altitude and a $\mathrm{Cfb}$ climate type, according to the Köppen classification. It also presents $21.5{ }^{\circ} \mathrm{C}$ mean annual temperature; $1,617 \mathrm{~mm}$ mean annual rainfall; and $62.0 \%$ mean annual relative air humidity (Godoy et al., 1976). Climatic data recorded during the experimental period are showed on Fig. 1. The chemical analysis of soil samples from the experimental area, in the $0-0.20 \mathrm{~m}$ deep layer, collected before setting up the experiment, shows the following composition: $\mathrm{pH}$ $\left(\mathrm{CaCl}_{2}\right), 5.2 ; \mathrm{pH}$ (water), 6.4; $\mathrm{Al}^{3+}\left(\mathrm{cmol}_{\mathrm{c}} \cdot \mathrm{dm}^{-3}\right)$, $0.00 ; \mathrm{H}^{+}+\mathrm{Al}^{3+}\left(\mathrm{cmol}_{\mathrm{c}} \cdot \mathrm{dm}^{-3}\right), 3.17 ; \mathrm{Ca}^{2+}+\mathrm{Mg}^{2+}$ $\left(\mathrm{cmol}_{\mathrm{c}} \cdot \mathrm{dm}^{-3}\right), 2.44 ; \mathrm{Ca}^{2+}\left(\mathrm{cmol}_{\mathrm{c}} \cdot \mathrm{dm}^{-3}\right), 1.49 ; \mathrm{K}^{+}$ $\left(\mathrm{cmol}_{\mathrm{c}} \cdot \mathrm{dm}^{-3}\right), 0.32 ; \mathrm{P}\left(\mathrm{mg} \cdot \mathrm{dm}^{-3}\right), 5.0 ; \mathrm{C}\left(\mathrm{g} \cdot \mathrm{dm}^{-3}\right)$, 13.57 .

Five cassava cultivars were planted in August 1997. These were Mico, Fibra, IAC 13, IAC 14 and Fécula Branca, chosen based on their local adaptation (Vidigal Filho et al., 2000). A randomized complete block design with four replications and treatments arranged in split plots was used. The cultivars were randomly distributed in plots (main treatments) and the harvest times in the sub-plots (secondary treatments).

The plot dimensions were $17.6 \mathrm{~m} \times 22.0 \mathrm{~m}$, with $1.0 \mathrm{~m}$ between rows and $0.80 \mathrm{~m}$ among plants in the same row. The total area of each plot was $327.2 \mathrm{~m}^{2}$, with each of the 10 subdivisions (subplots) referring to a harvest period (Sagrilo et al., 2003). Each sub-plot was composed by a row of 22 plants and two lateral borders. The plants at the extremities of each sub-plot and the lateral borders were discarded. The sub-plot useful area $\left(16.0 \mathrm{~m}^{2}\right)$ comprised 20 plants, from which six were randomly chosen for harvest at each data collection (Veltkamp, 1985), from August 1998 $\left(12^{\text {th }}\right.$ month after planting) to May 1999 (21 ${ }^{\text {th }}$ month after planting). The aerial part of these representative plants was divided into leaf blades, petioles and stems. Leaf blades and petioles were weighed to determine the total production of fresh leaves per unit area.

Sixty grams samples of leaf blades, petioles and stems were taken. Stems were cut in cubes of approximately $0.01 \mathrm{~m}$ and dried at $60^{\circ} \mathrm{C}$ in a forced air oven until constant weight, to determine their respective dry matter contents (Sales Filho, 1980). Leaf blades and petioles were dried at $45^{\circ} \mathrm{C}$ to obtain the dry matter (Silva, 1981).

From the other plants of each sub-plot, 20 storage roots were randomly taken and their diameter was determined from the central part of each root with a sliding caliper. Afterwards, a sample of these storage roots was submitted to the hydrostatic balance method as described by Grossmann and Freitas (1950) to estimate their dry matter content. The correlation between sample weight in water and its dry matter content after drying at $105^{\circ} \mathrm{C}$ showed that the dry matter content in roots increased in the order of $0.0564 \%$ per each increase unit on sample weight in water. Thus, the following equation is obtained: $\mathrm{Y}=15.75+0.0564$ $\mathrm{x}$, where " $\mathrm{Y}$ " is the dry matter content and " $\mathrm{x}$ ", is the 3-kg sample weight in water.

The data were submitted to analysis of variance for the main effects (cultivars and harvest period) as well as for their interaction (cultivars $\mathrm{x}$ harvest period). When significant interaction was observed, adequate statistical procedures were performed, according to Banzatto and Kronka (1995) recommendations. Cultivars means were compared by the Tukey test at $5 \%$ of probability, while the harvest time means were analyzed by polynomial equation models. For storage roots diameters, however, a logistic model of four parameters was fitted, that is: $\hat{y}=a+b /(1+\exp$ $(-(\mathrm{x}-\mathrm{c}) / \mathrm{d}))$. These according to Ratkowsky (1990), described as the following: 'a' parameter corresponds to the minimum asymptote; ' $b$ ' parameter corresponds to the difference between the maximum and minimum asymptote; ' $c$ ' parameter corresponds to the curve inflection point; ' $d$ ' parameter describes the curve declivity and; $\mathrm{x}=$ harvest period.

\section{RESULTS AND DISCUSSION}

The analysis of variance showed a significant effect $(\mathrm{P} \leq 0,05)$ of cultivars for the total production of fresh leaves, dry matter content in the leaf blades, stems and storage roots and, nonsignificant effect $(\mathrm{P}>0,05)$, for the dry matter content in the petioles and storage roots diameter. The effect of harvest period was significant for all the variables studied. However, the interaction between cultivars and harvest periods showed a non-significant effect only for the storage roots 
diameter, being necessary to adjust a mathematical model from the general means of the five cultivars in each harvest period. For the other characteristics, witch had significant interaction, a mathematical model was fitted to each cultivar.

1) Total production of fresh leaves: The variations observed in all the cultivars along the second plant vegetative cycle allowed the adjustment of polynomial equations of quadratic order $\left(y=a+b x+c x^{2}\right)$. This behavior was characterized by very low means of total fresh leaves production at 12 months, followed by a significant increase of production until the 16.57 months of age in the cultivar means, with a new decrease at 21 months of age (Fig. 2).

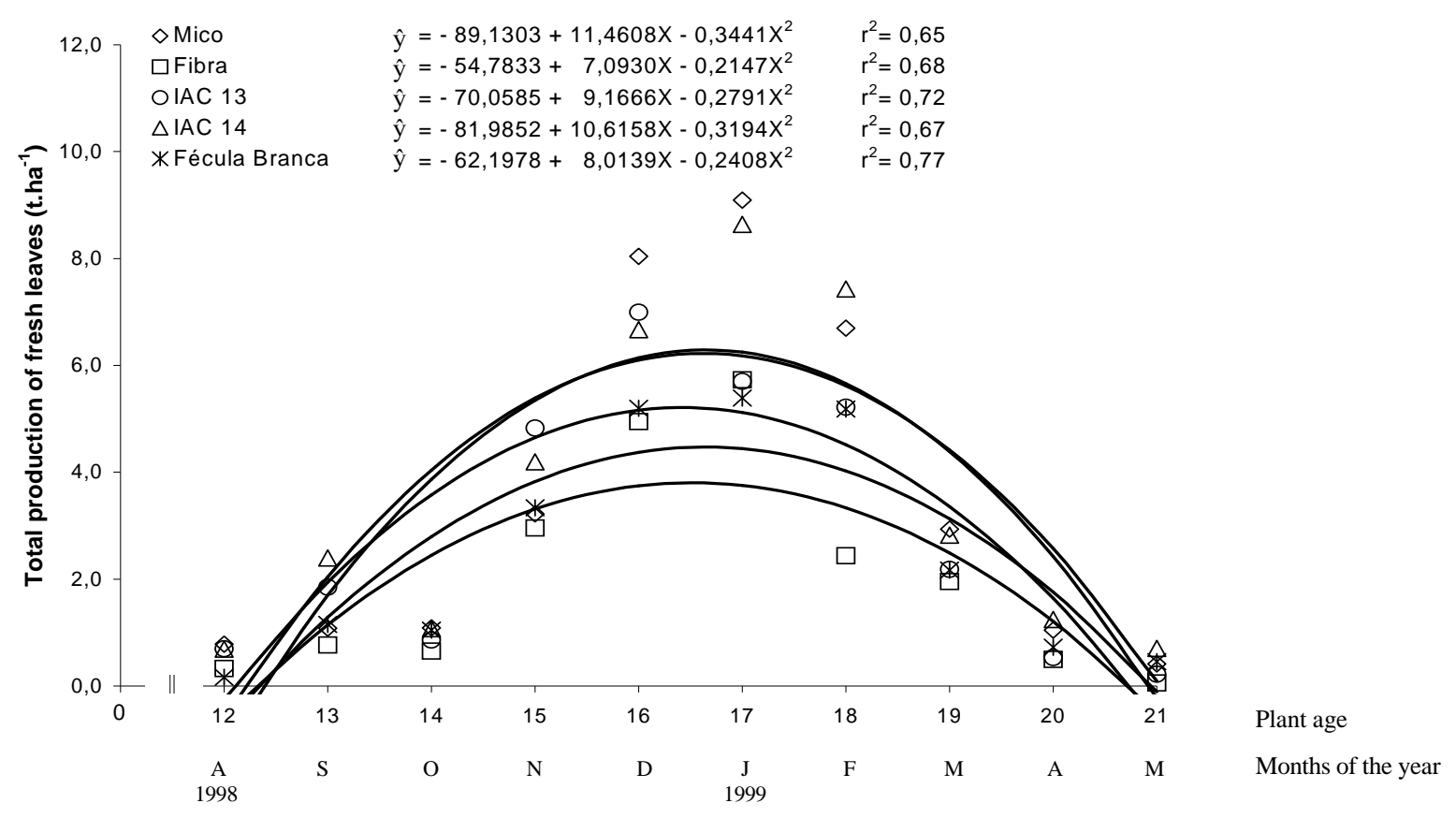

Figure 2 - Total production of fresh leaves $\left(\mathrm{t} . h a^{-1}\right)$ of five cassava cultivars, in 10 harvest times, during the second plant cycle (12 to 21 months). Araruna, Paraná, 2001.

The total production of fresh leaves seemed to be related to climatic variations along the harvesting period, especially, those related to temperature. According to Fig. 1, there was an increase in the mean temperatures from August onward, reaching maximum values between December and January, and a posterior decrease. This temperature increase coincided with the total production of fresh leaves. Sangoi and Kruse (1993), for the climatic conditions of Santa Catarina, south region of Brazil, also reported that the proximity of the end of the summer and the consequent reduction of atmospheric temperature resulted in a considerable foliar senescence increase. Takahashi (1998) also reported similar results for the climatic conditions of Northwest of Paraná State - Brazil. However, the data obtained by Távora and Barbosa Filho (1994), on Ceará, northeast region of Brazil, indicated that the amount of foliage depended not only on the climatic conditions, but also, strongly on the plant age. The reduction of leaves amount along the plant cycle was a normal fact and that the cycle could be accelerated, or retarded by the climactic conditions. According to Taiz and Zeiger (1998), the leaves drop was a kind of sequential senescence, which occured as they reached a certain age. For the cassava, this age varied from 60 to 120 days (Lorenzi and Dias, 1993). Alves (2002) also attributed the decrease in leaves production to the age of cassava plant and emphased that the foliar area was crucial in determining the culture growth and the dry matter accumulation rate in the storage roots.

In relation to the cultivars, it was observed that only at 16,17 and 18 months of age, there were significant differences between the means; the period that coincided with the maximum leaves production. In these months, Mico and IAC 14 
cultivars presented, in general, the highest values, although at 16 months, IAC 13 had statistically equalized to them. In general, Fibra and Fécula Branca presented the lowest means. In the following months, there were non-significant differences among the cultivars, indicating that there was no tendency of any of them, to present a faster rate of leaf area formation, or a longer leaf area duration. A possible differentiation among the cultivars in relation to these attributes would represent a desirable factor, considering that, according to Cock et al. (1979) and reinforced by Sangoi and Kruse (1993), the life cycle increase of the leaves would be related to a longer period of the photosynthesis, and consequently to the increment in the storage roots yield.

2) Dry matter content in the leaf blades: The dry matter content variation in the leaf blades (Fig. 3) allowed the adjustment of a linear model for each assessed cultivar $(y=a+b x)$. Based on the equations obtained, the leaf blades tended to increase their dry matter contents along the harvest period, with increases in the order of $124.22 \%$, in the case of Fibra cultivar.

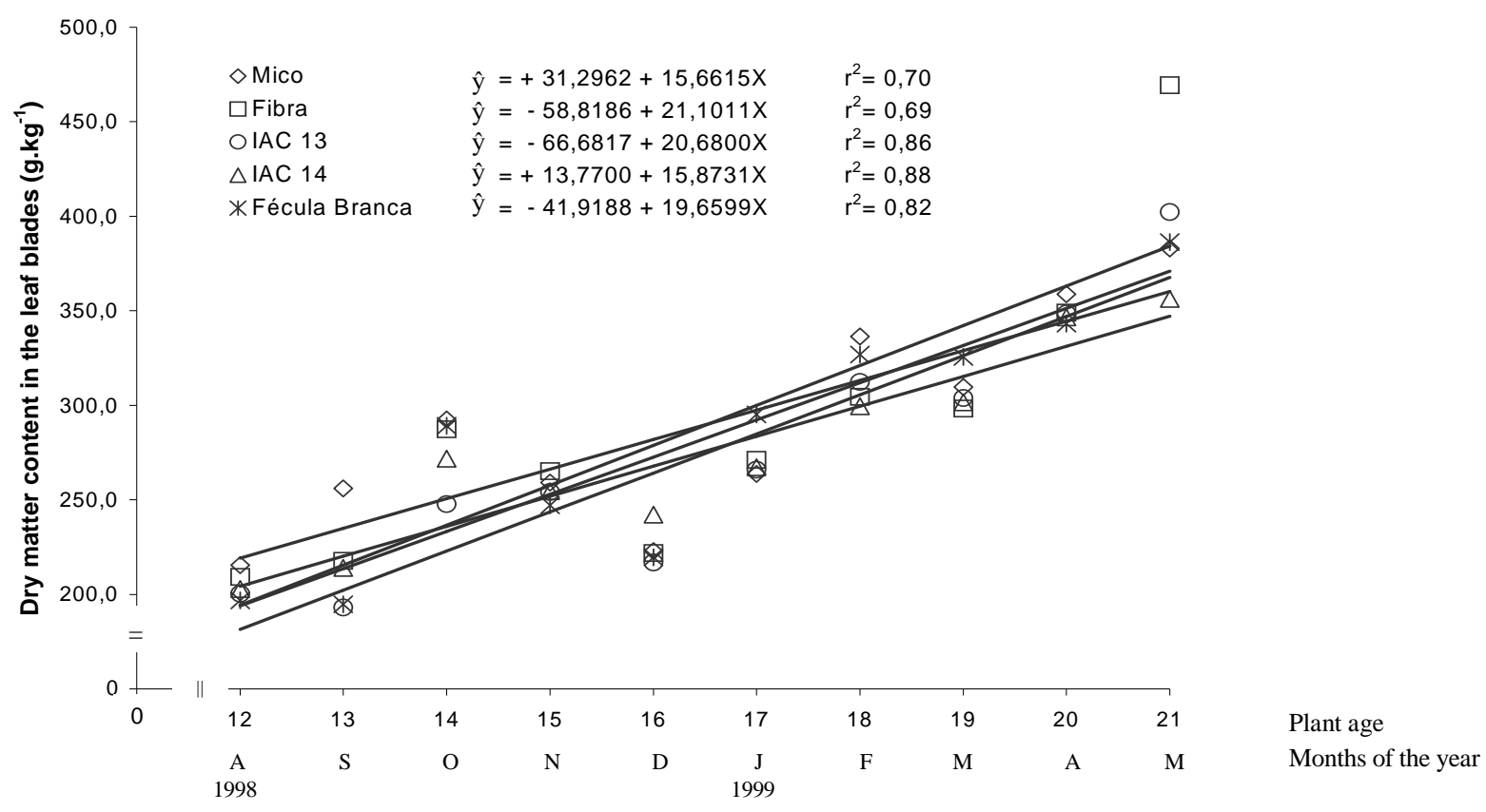

Figure 3 - Dry matter content in the leaf blades $\left(\mathrm{g} \cdot \mathrm{kg}^{-1}\right)$ of five cassava cultivars, at 10 harvest times, during the second plant cycle (12 to 21 months). Araruna, Paraná, 2001.

Carvalho et al. (1985) showed the variation in the humidity content of the superior portion of cassava plants (leafy portion). The highest humidity was observed in the period of more intense leaf production. This was due to the high rainfall intensity observed in the period. However, the variations found in this study were not affected by climate, considering that the plants expressed a continuous increase of the dry matter contents, even during the period of most intense vegetative growth.

According to Tineo (1978), there is a higher accumulation of dry matter in the leaves with the time due to the tissue lignification. However, for the present study in any of the harvests the leaf blade samples taken analysis contained old and young leaves. However, it was probable that as the plant aged, the chances of being taken older leaves for sample were superior due to the increase of foliar senescence after the complete aerial part formation in the second life cycle. Furthermore, in that period, the production rate of new leaves decreases (Alves, 2002). This fact can explain, therefore, at least in part, the constant increase of dry matter in the leaf blades in the second plant cycle. Another possibility, however, could be related to the fact that, according to Alves (2002), the size, the morphology, and other agronomical 
characteristic of the cassava leaves varied according to the environment and the plant age. This was reinforced by Conceição (1981) and indicated, therefore, that the increase of dry matter contents present in the leaf blades could be related to ontogenetical factors inherent to the cassava plant itself.

Regarding the cultivars, the data obtained showed that in most harvest times, there were no significant differences among means, except for the harvest at 13,14 and 21 months of the plant age. At $13^{\text {th }}$ month, Mico, Fibra and IAC 14 cultivars presented superior means. In the following month, besides these cultivars, Fécula Branca presented superior dry matter content in the leaf blades. But at 21 months of age, Fibra exceeded over all, perhaps, as a consequence of the superior accumulation rate of dry matter, which resulted in an average $124.22 \%$ superior to that observed in the beginning of the harvest or due to the low production rate of new leaves, observed for this cultivar.

3) Dry matter content in the petioles: The data obtained for this characteristic (Fig. 4) were similar to those presented for the dry matter content in the leaf blades (Fig. 3) allowing, thus, the adjustment of a linear polynomial model $(y=a$ $+\mathrm{bx})$. The behavior expressed by the equations adjusted for each cultivar evidenced continuous increase of the dry matter contents in the petioles. However numerical values showed were comparatively inferior to those observed to the leaf blades. The magnitude of the variations found between the first and the last harvest surpassed remarkably the values observed to the dry matter contents in the leaf blades. These variations were, at average of $146.65 \%$ between the first and the last harvest.

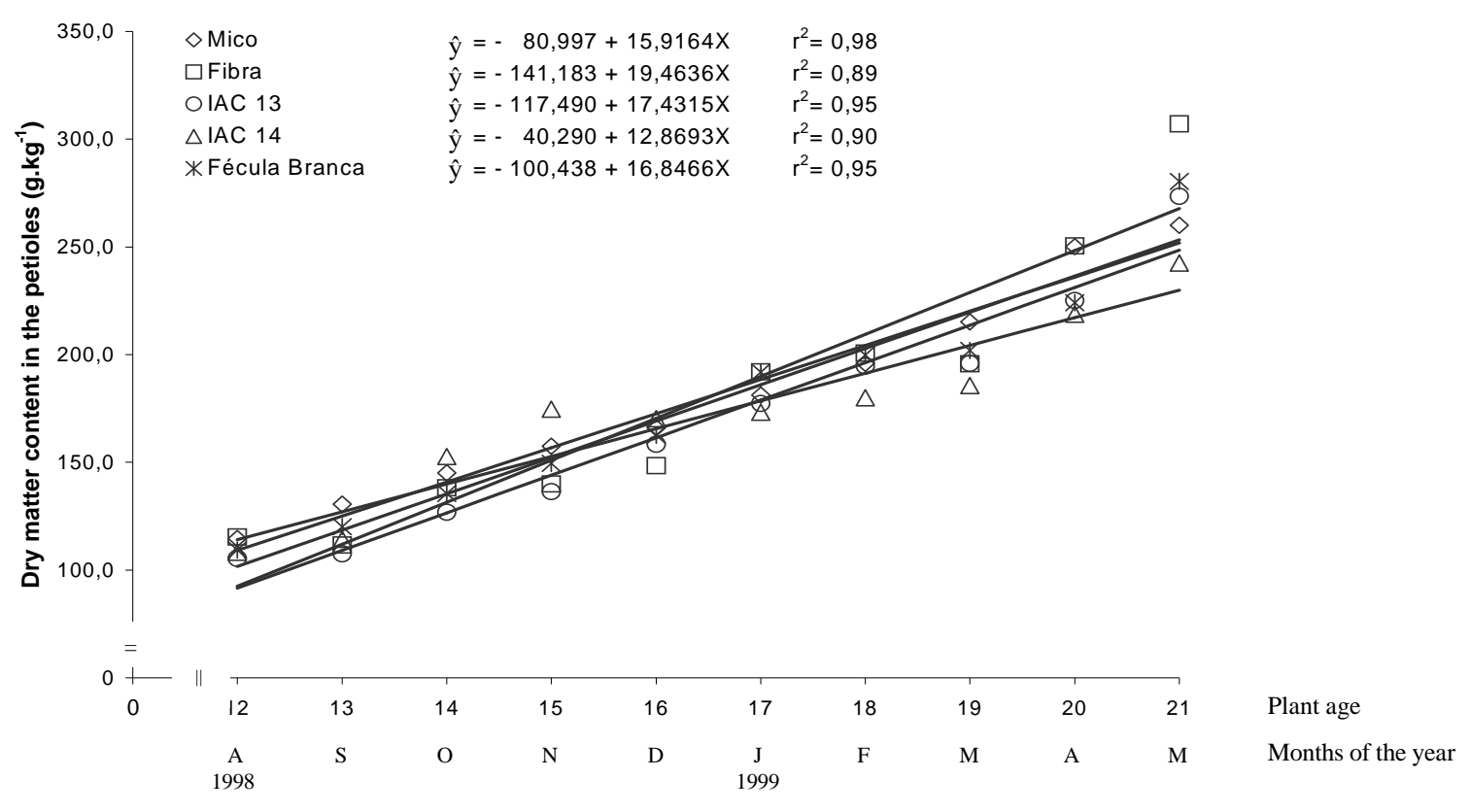

Figure 4 - Dry matter content in the petioles $\left(\mathrm{g}_{\mathrm{kg}} \mathrm{kg}^{-1}\right)$ of five cassava cultivars, at 10 harvest times, during the second plant cycle (12 to 21 months). Araruna, Paraná, 2001.

Regarding the cultivars, significant mean differences were found only at 15 and 21 months of age. At 15 months, it was observed that IAC 14 cultivar presented superior values, while IAC 13 inferior ones, not differing from Mico, Fibra, Fécula Branca and IAC 13. The cultivars that presented superior means in the last harvest, corresponded to those of superior percentile increment in the dry matter of the petioles. It was observed that although the dry matter content in the petioles were similar to the dry matter content in the leaf blades (Fig. 3), the cultivar behavior did not describe the same quality of both variables. Possibly, this difference occurred because of the 
ambiguity presented by the leaf blades, some times acting as a sink (beginning of its formation), another times acting as a source (Alves, 2002), whereas the petioles did not present significant attribute of source. These differences could have contributed for the cultivar variations as to the dry matter content in the leaf blades and in the petioles.

4) Dry matter content in the stems: This characteristic showed a behavior explained (Fig. 5) through polynomial models of cubic order $(y=a+$ $\left.\mathrm{bx}+\mathrm{cx}^{2}+\mathrm{dx}^{3}\right)$. It was noticed that at the beginning of harvest period (at 12 months), the plants showed high dry matter content in the stems, with differentiated amplitude for each cultivar. After this harvest, the means decreased sharply and the period with lower values occurred when the plants aged 14.61 months. From this period onward, an increase in averages for all cultivars was observed with a peak of greatest accumulation at the age of 19.40 months and a new tendency to decrease the means until the last harvest. Both the minimum period and the maximum accumulation of dry matter in the stems were obtained from the first derivation of adjusted polynomial functions, as presented in the means of the cultivars.

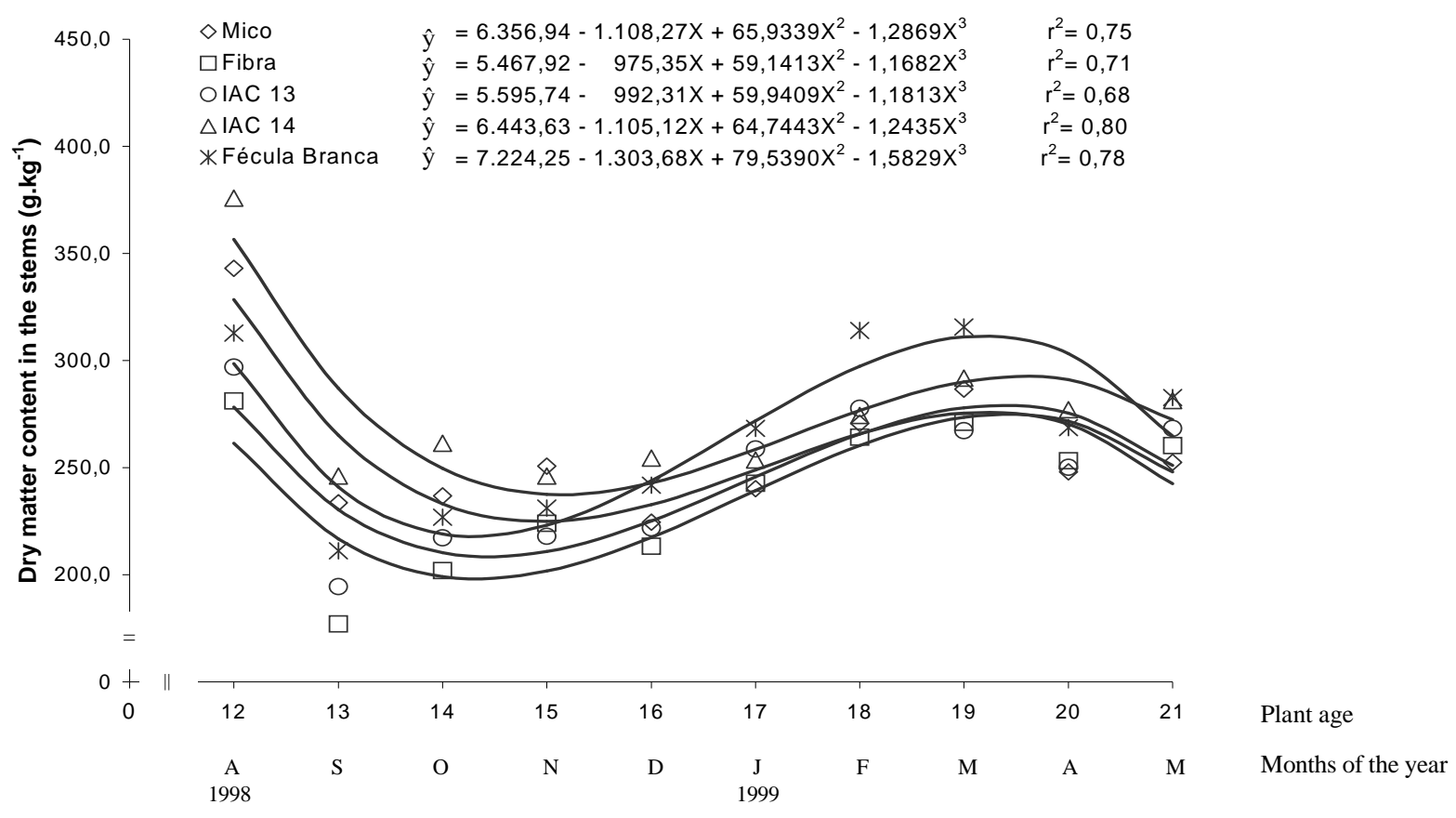

Figure 5 - Dry matter content in the stems $\left(\mathrm{g} \cdot \mathrm{kg}^{-1}\right)$ of five cassava cultivars, at ten harvest times, during the second plant cycle (12 to 21 months). Araruna, Paraná, 2001.

In the months related to the first harvests, the intensive process of new leaves formation (Fig. 2) was the main cause of the decrease in the dry matter content in the stems, as observed in all the cultivars. This process constituted a strong sink (Alves, 2002) of carbohydrates stored in the stems. According to Madore (1994), when there is a large demand of carbohydrates, they can be carried to the phloem. Similarly to this assertion, Conceição (1981) and Lorenzi and Dias (1993) state that at the beginning of second period of vegetative growth of cassava plants, the buds from the superior portion started their vegetative activity utilizing the accumulated reserves in the stems of plants and other parts as well. As a result, there was a reduction in starch content, and consequently, in the dry matter.

The increase of dry matter content in the stems which was observed from the 14.61 months with a peak of high accumulation at 19.40 months - had the full resumption of plant photosynthesis as a conditioning factor, because the plants, in that period, had their leaf structure totally developed. The subsequent mean decrease, observed at 21 
months, indicated an approximation of a new period of physiological rest, characterized for stagnation in great part of metabolic activities and maintenance of stem flow assimilates for the storage roots, according to Sales Filho (1980), Conceição (1981), Sangoi and Kruse (1993) and Alves (2002).

In relation to the differences found among the cultivars, in the first three harvest times, IAC 14 cultivar showed the highest means, although it was not significantly different from Mico at the age of 13 and 14 months. At 15 months, IAC 13 showed the lowest means whereas the other cultivars were superior, but they did not differ. At 16 months, IAC 14 showed the highest means again, but it did not differ from Fécula Branca. At 17 months, no significant difference was noticed among the cultivars, nevertheless, from the age of 18 months, Fécula Branca started to be superior to the other cultivars and equaled only IAC 14 (aged from 14 to 19 months) and Fibra, IAC 13 and IAC 14 (aged 20 and 21 months).

The results indicated that the differences among the cultivars were more evident in the periods of high dry matter contents in the stems, as opposed to periods with lower contents. This suggested that some cultivars showed more capacity for accumulating dry matter in the stems, which could be more efficiently used by plants in periods of vegetative re-growth, because they could involve, in less proportion, the dry matter stored in the roots (Sales Filho, 1980; Conceição, 1981; Sangoi and Kruse, 1993).

\section{5) Evaluation of dry matter content in the} storage roots: It was observed that the variations in the obtained data allowed the adjustment of polynomial models of cubic order $(y=a+b x+$ $\mathrm{cx}^{2}+\mathrm{dx}^{3}$ ) to explain the biological behavior of each cultivar. The data showed in Fig. 6 indicated that in the first harvest (12 months), the values were high, and turned to decrease by 15 months exactly. From this period onward, the plants returned to accumulate reserves in the storage roots, with maximum peak at 20.77 months (means of the cultivars).

At 12 months, the plants were at the end of the first phase of physiological rest. This explained the high dry matter contents in the storage roots. The following months were characterized by the beginning of a new cycle of the plant vegetative development.

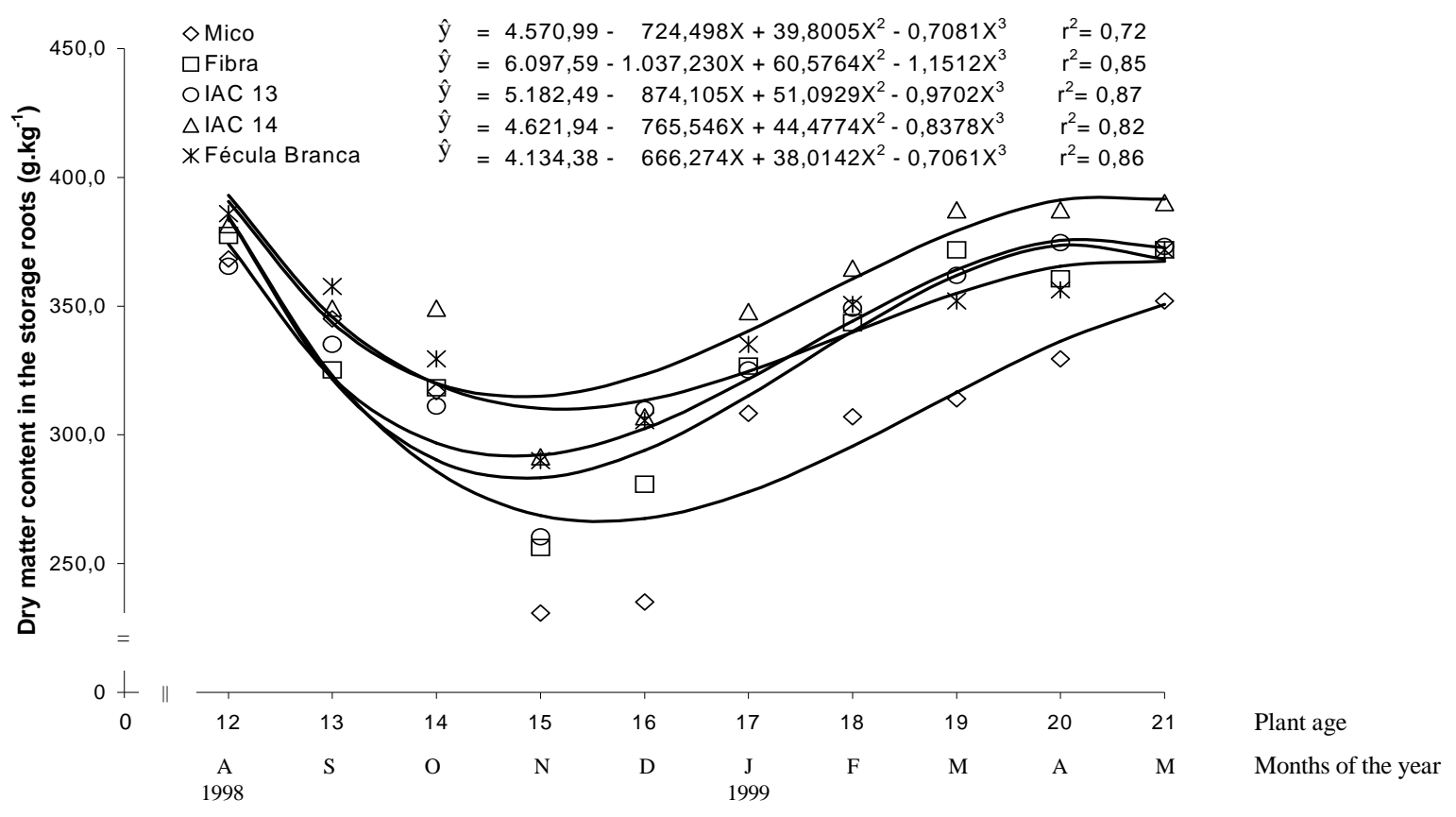

Figure 6 - Dry matter content in the storage roots $\left(\mathrm{g} \cdot \mathrm{kg}^{-1}\right)$ of five cassava cultivars, at ten harvest times, during the second plant cycle (12 to 21 months). Araruna, Paraná, 2001. 
Part of the reserves that were in the roots was mobilized in order to serve the demand of formation of the new plant vegetative structures, especially the leaves (Fig. 2). This was in accordance to the data obtained by Keating et al. (1982) in Australia, which reported that the period of plant physiological rest represented the best harvest time, because of the high production of storage roots and dry matter. The harvest delay resulted in reduction of dry matter content because of the mobilization of carbohydrates to support the new organs in growth.

The new period of dry matter accumulation in the storage roots that followed until the age of 20.77 months resulted from the full structure of plant foliage, as presented in Fig. 2. This behavior was related by Hammer et al. (1987) and Hobman et al. (1987) for Australia conditions, stating that the dry matter contents in the storage roots were high in periods of low growth and vegetative rest, showing outstanding decrease during the periods of regeneration of the aerial part.

Another point refered to minimum and maximum dry matter content in the storage roots, which were obtained by the first derivation of polynomial functions. Although the curve shape was similar to the one observed to the dry matter content in the stems (Fig. 5), the minimum dry matter contents in the storage roots occurred at 15 months. It was possible to say that the source role performed by the stems supported for some time the sprout process of the plants in the second cycle and only after the exhaust of their reserves, the roots contributed more significantly by supplying carbohydrates to the aerial part. At the same way, the maximum accumulation of dry matter occurred in the stems aged 19.40 months, while in the storage roots, this occurred at the age of 20.77 months, over one month later. In this case, assimilates that were produced by photosynthesis apparatus restored fully the dry matter contents first in the stem and, only after that, in the storage roots. It indicated that the plant stem could constitute a preferential drain, in the initial period in which the balance of carbohydrates started to be positive.

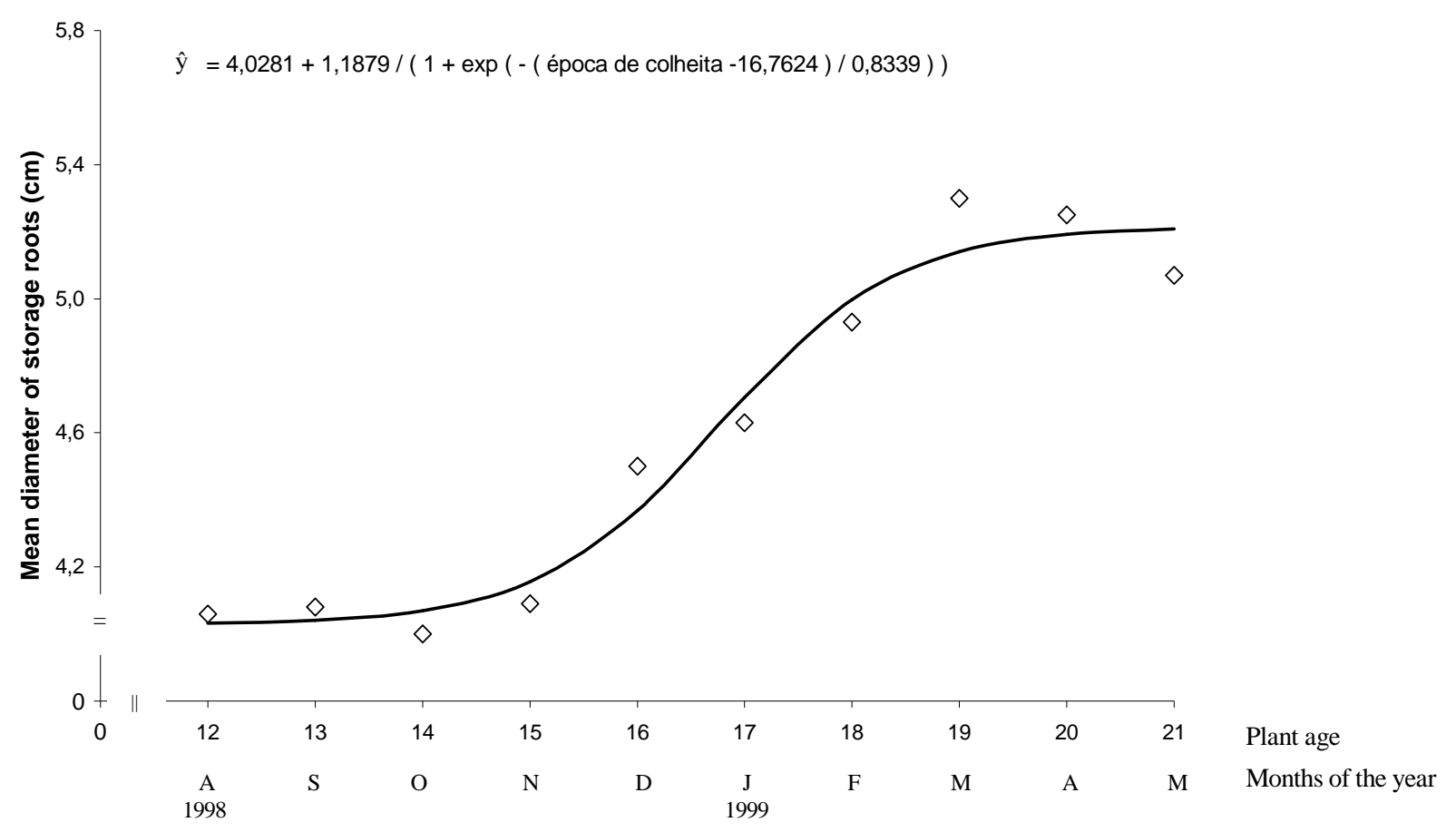

Figure 7 - Average of storage roots $(\mathrm{cm})$ of five cassava cultivars, at ten harvest times, during the second plant cycle (12 to 21 months). Araruna, Paraná, 2001. 
There was an existence of a significant difference among the cultivars, only from 14 months onward when IAC 14, Fécula Branca, Fibra and Mico showed the highest means. However, from 15 to 21 months, IAC 14, Fécula Branca, IAC 13 and Fibra cultivars surpassed Mico, but they did not differ. The superiority of IAC 14, IAC 13 and Fécula Branca, in relation to the dry matter content in the storage roots, was also observed by Vidigal Filho et al. (2000) in the northwest of Paraná, in plants with one vegetative cycle. Emphasis must be placed on the fact that the cultivars that were responsible for high dry matter contents in the storage roots were also those with high dry matter contents in the stems, especially in periods of maximum accumulation (Fig. 5). It reinforced the importance of the stems, because they provided carbohydrates supply to the aerial part in regeneration phase, as opposed to carbohydrates stored in the storage roots.

6) Mean diameter of storage roots: The variations found for this characteristic along 10 harvest dates obeyed a non-linear behavior, which was explained mathematically by a sigmoid model (Fig. 7). It was observed that the mean diameter of storage roots remained practically unchangeable, from 12 to 15 months, in a plateau, with mean values around to $4.0 \mathrm{~cm}$. From the age of 15 to 19 months, there was an accelerated increase in the mean diameter of storage roots, reaching a new plateau, with mean values around $5.2 \mathrm{~cm}$.

These variations coincided with normal behavior of cassava plant during the second cycle, which according to Montaldo (1979) consisted of development of new stems and leaves, thickener storage roots and rest. These phases were quite evident in the present study, especially in the period of greatest increase in diameter that corresponded to the phase of high leaf production. These results could be considered important as the increase of diameter in the storage roots was an attribute directly related to the production of storage roots (Williams, 1974); radial diameter of storage roots to be the main component of production and that the weight of storage roots were functions of its diameter. Therefore, the results of the present study, showed the importance of leaves production and their influence in the production of storage roots (Cock et al., 1979; Veltkamp, 1985; Sangoi and Kruse, 1993).
General means obtained showed that there was not any significant difference in the diameter of storage roots among the cultivars. The obtained results were, on average, $4.6 \mathrm{~cm}$. This statistical equality among the cultivars was different from data presented by Williams (1974), who reported in Kuala Lumpur, Malaya, the existence of cultivars with similar storage roots length, but with wide variations in weight because of differences in their diameter.

\section{CONCLUSIONS}

- The leaves production was greater in high temperature period, and this was influenced by the age of the plant;

- The dry matter content in the leaf blades and petioles increased continually as the plant aged, being related to the low proportion of young leaves and ontogenetic factors of the plant;

- The role of source, exerted by the stems, supported, temporarily, the vegetative restructure of the plants, involving, in less proportion, the carbohydrates present in the storage roots;

- The dry matter contents in the storage roots were lower in the period of re-structure of vegetative portion and higher in the phase of physiological rest of plants;

- The storage roots diameter increased considerably when the amount of leaves was higher, indicating the importance of leaf production in the cassava yield components.

\section{ACKNOWLEDGEMENTS}

The authors would like to thank Capes, CNPq and Pinduca - Indústria Alimentícia Ltda for funding the project.

\section{RESUMO}

O experimento foi conduzido de outubro de 1997 a maio de 1999, no Noroeste do Paraná, Brasil, com o objetivo de avaliar o padrão de produção de folhas e distribuição de massa seca em 5 cultivares de mandioca, durante o segundo ciclo vegetativo. Utilizou-se o delineamento experimental em blocos casualizados, com 4 repetições, no esquema 
de parcelas subdivididas, estando as cultivares nas parcelas e as épocas de colheita nas subparcelas. A produção de folhas foi afetada pela idade das plantas, sendo maior nos períodos de temperatura elevada. Os teores de massa seca nos limbos foliares e pecíolos aumentaram linearmente com a idade das plantas, devido à menor proporção de folhas jovens e a fatores ontogênicos inerentes à planta. As hastes proporcionaram, temporariamente, os assimilados necessários para a reestruturação vegetativa das plantas, protelando a disponibilidade e uso dos carboidratos armazenados nas raízes. O teor de massa seca nas raízes foi menor durante o período de crescimento vegetativo e maior, durante o período de repouso fisiológico. O diâmetro das raízes aumentou, consideravelmente, no período de maior enfolhamento, indicando a importância da produção de folhas nos componentes de produção da mandioca.

\section{REFERENCES}

Alves, A. A. C. (2002), Cassava botany and physiology. In: Hillocks, R. J.; Thresh, J. M. and Bellotti, A. C. (Eds.). Cassava: biology, production and utilization. UK: Cabi Publishing. pp. 67-89.

Banzatto, D. A. and Kronka, S. N. (1995), Experimentação agrícola. 3. ed. Jaboticabal: FUNEP.

Cardoso, C. E. L. and Souza, J. S. (2002), Importância, potencialidades e perspectivas do cultivo da mandioca na América Latina. In: Cereda, M. P. (Coord.). Agricultura: tuberosas amiláceas latino americanas Cultura de tuberosas amiláceas latino americanas. São Paulo: Fundação Cargill. v. 2. pp. 29-47.

Carvalho, V. D.; Paula, M. B. and Juste Jr., E. S. G. (1985), Efeito da época de colheita no rendimento e composição química de fenos de parte aérea de dez cultivares de mandioca. Revista Brasileira de Mandioca, 4, 43-59.

Cock, J. H. (1984), Cassava. In: Goldsworth, P. R. and Fisher, N. M. (Eds.). The physiology of tropical field crops. Chichester: J. Wiley. pp. 529-549.

Cock, J. H.; Franklin, D.; Sandoval, G. and Juri, P. (1979), The ideal cassava plant for maximum yield. Crop Science, 19, 271-279.

Conceição, A. J. (1981), A mandioca. 3. ed. São Paulo: Nobel.

Doreto, M. (1993), Distribuição da cultura da mandioca no Paraná nos anos 80. Londrina: IAPAR. 19 pp. (Informe de Pesquisa, 102).

El-Sharkawy, M. A. (1993), Drought-tolerant cassava for Africa, Asia and Latin America. Bioscience, 43, 441-451.
Embrapa (1999), Sistema brasileiro de classificação de solos. Rio de Janeiro: CNPS.

Godoy, H.; Correia, A. R. and Santos, D. (1976), Clima do Paraná. In: Manual agropecuário para o Paraná 1976. Londrina: IAPAR. pp. 17-36.

Grosmann, I. and Freitas, A. C. (1950), Determinação do teor de matéria seca pelo peso específico em raízes de mandioca. Revista Agronômica, 14, 75-80.

Hammer, G. L.; Hobman, F. R. and Shepherd, R.K. (1987), Effects of planting time and harvest age on cassava (Manihot esculenta) in Northern Australia. I. Crop growth and yield in moist environments. Experimental Agriculture, 23, 401-414.

Hobman, F. R.; Hammer, G. L. and Shepherd, R. K. (1987), Effects of planting time and harvest age on cassava (Manihot esculenta) in Northern Australia. II. Crop growth and yield in a seasonally-dry environment. Experimental Agriculture, 23, 415-424.

IBGE (2003), Sistema IBGE de recuperação automática. Available at: <http://www.sidra.ibge. gov.br/bda/agric >. Accessed in: February 10 ${ }^{\text {th }}, 2003$.

Jesus, V. S.; Moraes, C. F.; Teles, F. F. F. and Sediyama, C. S. (1986), Teor de carboidrato em raízes e caules de dez variedades de mandioca (Manihot esculenta, Crantz), durante o primeiro ciclo. Revista Brasileira de Mandioca, 5, 91-98.

Keating, B. A.; Evenson, J. P. and Fukai, S. (1982), Environmental effects on growth and development of cassava (Manihot esculenta, Crantz). III. Assimilate distribution and storage organ yield. Field Crops Research, 5, 293-303.

Lorenzi, J. O. and Dias, C. A. C. (1993), Cultura da mandioca. Campinas: Coordenadoria de Assistência Técnica Integral. 41 pp. (Boletim Técnico, 211).

Madore, M. A. (1994), Phloem transport of solutes in crop plants. In: Pessorakli, M. (Ed.). Handbook of plant and crop physiology. Tucson: The University of Arizona. pp. 337-353.

Montaldo, A. (1979), La yuca. San Jose: IICA.

Ratkowsky, D. A. (1990), Handbook of nonlinear regression models. New York: Marcel Dekker.

Sagrilo, E.; Vidigal Filho, P. S.; Pequeno, M. G. (2002a), Épocas de colheita de parte aérea e de raízes tuberosas de mandioca. In: Cereda, M. P. (Coord.). Agricultura: tuberosas amiláceas latino americanas Cultura de tuberosas amiláceas latino americanas. São Paulo: Fundação Cargill. v. 2. pp. 384-412.

Sagrilo, E.; Vidigal Filho, P. S.; Pequeno, M. G.; Scapim, C. A.; Gonçalves-Vidigal, M. C.; Maia, R. R. and Kvitschal, M. V. (2002b), Efeito da época de colheita no crescimento vegetativo, produtividade e qualidade de raízes de três cultivares de mandioca (Manihot esculenta, Crantz). Bragantia, 61, 115-125. 
Sagrilo, E.; Vidigal Filho, P. S.; Pequeno, M. G.; Scapim, C. A.; Gonçalves-Vidigal, M. C.; Souza Diniz, P. S. S.; Modesto, E. C. and Kvitschal, M. V. Effect of Harvest Period on the Quality of storage roots and protein content of the leaves in five cassava cultivars (Manihot esculenta, Crantz). Brazilian Arch. Biol. Tech., 46 (2), 295-305.

Sales Filho, J. B. (1980), Distribuição de carboidratos em plantas de mandioca (Manihot esculenta, Crantz) $e$ o efeito do teor de reservas, na brotação $e$ enraizamento de estacas de três posições do caule. Tese (Mestrado em Fitotecnia) - Universidade Federal de Viçosa, Viçosa.

Sangoi, L. and Kruse, N. D. (1993), Acúmulo e distribuição de matéria seca em diferentes frações da planta de mandioca no planalto catarinense. Pesquisa Agropecuária Brasileira, 28, 1151-1164.

Scott, G.; Rosegrand, M. W. and Bokanga, M. (2000), Roots and tubers for $21^{\text {th }}$ century: trends, projections, and policy options. Lima: International Potato Center. $64 \mathrm{pp}$.

Silva, D. J. (1981), Análise de alimentos: métodos químicos e biológicos. Viçosa: Imprensa Universitária da UFV.

Takahashi, M. (1998), Épocas de poda na cultura da mandioca na região Noroeste do Estado do Paraná, Brasil. Braz. Arch. Biol. Technol., 41 : (1), 495-500.

Taiz, L. and Zeiger, E. (1998), Plant physiology. 2. ed. Sunderland, Massachusetts: Sinauer.

Távora, F. J. A. F. and Barbosa Filho, M. (1994), Antecipação de plantio, com irrigação suplementar, no crescimento e produção de mandioca. Pesquisa Agropecuária Brasileira, 29, 1915-1926.

Tineo G. J. R. (1978), Algunas características del follage de la yuca (Manihot esculenta Crantz). Revista de la Facultad de Agronomia (LUZ), 5, 429-437.
Veltkamp, H. J. (1985), Physiological causes of yield variation in cassava (Manihot esculenta, Crantz). $\mathrm{PhD}$ Thesis, Agric. Univ. Wageningen Papers, Wageningen. v.85/86.

Vidigal Filho, P. S.; Pequeno, M. G.; Scapim, C. A.; Gonçalves-Vidigal, M. C.; Maia, R. R.; Sagrilo, E.; Simon, G. A. and Lima, R. S. (2000), Avaliação de cultivares de mandioca na região Noroeste do Paraná. Bragantia, 59, 69-75.

Williams, C. N. (1974), Growth and productivity of tapioca (Manihot utilissima, Pohl). IV. Development and yield of tubers. Experimental Agriculture, 10, 9-16.
Received: February 05, 2004; Revised: March 14, 2005; Accepted: October 19, 2006. 